\title{
Effects of Cycloheximide on the Response of
}

\section{Intestinal Mucosa to Cholera Enterotoxin}

\author{
Daniel V. Kimberg, Michael Field, Elaine Gershon, \\ Robert T. Schooley, and ANTONia HeNderson \\ From the Department of Medicine, Harvard Medical School, and The \\ Gastrointestinal Unit of the Department of Medicine, Beth Israel Hospital, \\ Boston, Massachusetts 02215
}

A в S T R A C T Prior studies have indicated that effects of cholera enterotoxin (CT) on the small intestine are delayed in onset and involve an interaction with adenyl cyclase in the mucosa. It has also been shown that the administration of cycloheximide to rabbits in doses which inhibit crypt cell mitoses $(20 \mathrm{mg} / \mathrm{kg}$ ), diminishes CTinduced fluid production in jejunal loops. These latter studies have been interpreted as indications that CT-related intestinal secretion is a crypt cell function and that it is mediated by a CT-induced protein.

The present study was undertaken to delineate more precisely the nature of the interaction in the intestine between cycloheximide and cholera toxin. Pretreatment of rabbits with cycloheximide reduced by $60 \%$ the secretory response to $\mathrm{CT}$ in isolated ileal loops with intact blood supply. Sodium and chloride flux measurements on mucosa isolated from these and control loops indicated that this antisecretory effect of cycloheximide persists in vitro. Measurements of radioactive leucine incorporation into mucosal protein indicated that the dose of cycloheximide employed inhibited protein synthesis by $90 \%$. This inhibitory effect was shown to be independent of any effect of cycloheximide on amino acid uptake across the brush border. Measurements of adenyl cyclase activity and cyclic AMP levels in ileal mucosa of cycloheximide pretreated and control animals indicated that cycloheximide did not diminish the CT-induced increases in these parameters.

These observations demonstrate that cycloheximide reduces CT-induced intestinal fluid production without interfering with the CT-induced augmentation of adenyl cyclase activity or the consequent rise in cyclic AMP concentration. Since the antisecretory effect of cycloheximide persists in vitro, it probably involves a direct

Dr. Kimberg is the recipient of a Research Career Development Award, AM-19377.

Received for publication 5 October 1972 and in revised form 31 January 1973. interaction of the antibiotic with mucosal cell ion transport mechanisms rather than an indirect effect mediated by other humoral or neurogenic factors. The present observations also suggest that the secretory response of the intestine to CT involves neither the synthesis of new adenyl cyclase nor that of a protein modifying its activity.

\section{INTRODUCTION}

There is a great deal of evidence indicating that an active secretory process probably accounts for the gastrointestinal fluid and electrolyte losses resulting from the action of cholera enterotoxin $(\mathrm{CT})^{1}(1,2$; see also references 3-6 for reviews). Employing isolated rabbit ileal mucosa stripped of its muscularis and mounted in modified Ussing chambers, Field and his coworkers have demonstrated that application of CT to the luminal surface eliminates the normal transport of sodium from mucosa to serosa and reverses the normal direction of chloride transport such that net active chloride secretion occurs $(4,7)$. The active processes for the absorption of sugars and the associated enhancement of sodium absorption are not influenced by secretory stimuli such as $\operatorname{CT}(4,7)$.

Studies performed by Field and his colleagues and others have shown that cyclic $3^{\prime}, 5^{\prime}$-adenosine monophosphate (cyclic AMP), theophylline, and certain prostaglandins have effects on small intestinal ion transport which are similar to those noted after addition of CT $(4,8-11)$. These observations, coupled with the demonstration that the enterotoxin has cyclic AMP-like effects on isolated fat cells (12), liver, and platelets (13), suggested that the CT and prostaglandin-related intestinal

\footnotetext{
${ }^{1}$ Abbreviations used in this paper: CT, cholera enterotoxin; cyclic AMP, cyclic $3^{\prime}, 5^{\prime}$-adenosine monophosphate; dibutyryl cyclic AMP, $\mathrm{N}^{\circ}$-2' $O$-dibutyryl-cyclic $3^{\prime}, 5^{\prime}$-adenosine monophosphate; SCC, short-circuit current.
} 
fluid losses were mediated by means of an interaction with intestinal mucosal adenyl cyclase. More recent studies in this laboratory $(11)^{2}$ and in others $(14,15)$ have indeed demonstrated that CT and certain prostaglandins stimulate adenyl cyclase activity and elevate cyclic AMP levels in small intestinal mucosal cells.

Most effects of endogenous and exogenous hormonal stimuli on cyclic AMP metabolism occur within a matter of minutes. Characteristically, however, in the intestine and in the other systems studied, the effects of CT on cyclic AMP metabolism or in producing a physiologic response are often delayed $(4,7,11,12$ 1619). The nature of the events which occur during this lag period are presently unknown. Of interest in this regard are the observations of Serebro, Iber, Yardley, and Hendrix (20) and of others (21-23) concerned with the effects of cycloheximide, an inhibitor of protein synthesis, on CT-induced small intestinal fluid secretion in in vivo. Serebro and his coworkers (20) demonstrated that cycloheximide administered intravenously to rabbits $1 \mathrm{~h}$ before the intraluminal instillation of CT in jejunal loops, prevented the enterotoxin-induced production of fluid. Glucose absorption was unaffected, and the major histologic change in the epithelium was a decrease in mitoses in the crypts. Also of note are the observations of Harper, Yardley, and Hendrix (22) who found that in more prolonged studies, cycloheximide administration following the instillation of CT could reverse previously induced secretion. The results of these previous studies employing cycloheximide have been interpreted as indicating that intestinal secretion due to exposure to $\mathrm{CT}$ is mediated by an enterotoxininduced protein synthesized in crypt cells $(20,21)$.

The present studies were undertaken to determine if cycloheximide administration interferes with the stimulation by CT of intestinal mucosal adenyl cyclase activity and cyclic AMP levels, and to relate these effects (if any) to cycloheximide-induced inhibition of protein synthesis, and cycloheximide-induced alterations of intestinal ion transport.

\section{METHODS}

Animal preparation. New Zealand white, male rabbits weighing between 2 and $3 \mathrm{~kg}$ were anesthetized with intravenous pentobarbital sodium and locally administered lidocaine. Two distal ileal loops with intact blood supply were prepared with ligatures at both ends. Each loop was approximately $25 \mathrm{~cm}$ in length and the two loops were separated by a skip area of $10-15 \mathrm{~cm}$. Each of the two loops were cannulated at both ends with Tygon tubing secured by surgical silk ligatures, and the tubing was left open at each end. The loops were flushed with isotonic saline followed by air, and then returned to the abdomen which was closed. $\mathrm{Hy}-$ dration was provided with intravenous isotonic sodium chloride (approximately 10-20 ml per $\mathrm{h}$ ), and body tem-

\footnotetext{
${ }^{2}$ Kimberg, D. V., and M. Field. Unpublished observations.
}

perature was maintained with a heat lamp. After the preparation of the ileal loops, animals received either an intravenous injection of cycloheximide, $20 \mathrm{mg}$ per $\mathrm{kg}$ in isotonic saline, or of isotonic saline alone. $1 \mathrm{~h}$ later in a randomized manner, either the proximal or distal loop in each animal was filled with approximately $10 \mathrm{ml}$ of an $\mathrm{HCO}_{3}$-Ringer solution, while the remaining loop was filled with an identical solution which also contained purified cholera enterotoxin ${ }^{3}$ at a concentration of $1 \mu \mathrm{g}$ per $\mathrm{ml}$. The $\mathrm{HCO}_{3}$-Ringer solution ( $\mathrm{pH}$ 7.4) contained the following ions in millimoles per liter: $\mathrm{Na}, 141 ; \mathrm{K}, 10 ; \mathrm{Ca}, 1.25 ; \mathrm{Mg}$, $1.1 ; \mathrm{Cl}, 127 ; \mathrm{HCO}_{3}, 25 ; \mathrm{H}_{2} \mathrm{PO}_{4}, 0.3$; and $\mathrm{HPO}_{4}, 1.65 .1 \mathrm{~h}$ after the instillation of solutions into the loops, the abdomen was opened, the loops flushed with air, further drained by digital pressure, and the abdomen was then reclosed. During the ensuing $3 \mathrm{~h}$ fluid was collected from the cannulae, and at the end of this time the abdomen was reopened. The loops were drained and then flushed with air in order to collect the residual fluid. With the blood supply still intact, duplicate full thickness biopsies from each loop were taken for cyclic AMP measurements (see below). The intestinal loops were then removed, their lengths determined, and mucosa was rapidly obtained for additional studies described below.

Flux studies. Once excised, a portion of ileum from each loop was stripped free of muscularis and paired tissues from each loop were mounted in modified Ussing-type chambers as described previously (24). The tissues were bathed in the $\mathrm{HCO}_{3}$-Ringer solution gassed with $5 \% \quad \mathrm{CO}_{2}$ in $\mathrm{O}_{2}$ (see below). In those studies in which mucosa from cycloheximide pretreated animals was employed, cycloheximide at a concentration of $5.0 \times 10^{-5} \mathrm{M}$ was added to both the serosal and mucosal reservoirs. The methods for measuring shortcircuit current (SCC) and fluxes of ${ }^{22} \mathrm{Na}$ and ${ }^{30} \mathrm{Cl}$ (both obtained from New England Nuclear, Boston, Mass.) have been previously described (24). Fluxes were determined from initial samples taken $30-40 \mathrm{~min}$ after mounting in vitro and $20 \mathrm{~min}$ after adding radioisotopes and final samples taken 75-85 min after mounting tissues in vitro. 75-90 min after mounting the tissue and 5-10 min after completing $\mathrm{Na}$ and $\mathrm{C} 1$ flux measurements, $0.5 \mathrm{mM} \mathrm{N} \mathrm{N}^{6}-2^{\prime} O$-dibutyryl-cyclic $3^{\prime}, 5^{\prime}$-adenosine monophosphate (dibutyryl cyclic AMP) was added to the serosal compartment and the change in SCC determined over a 5 min period. Dibutyryl cyclic AMP was purchased as the monosodium salt from Boehringer Mannheim Corp., Mannheim, West Germany.

Protein synthesis. After removal of the control and CTexposed loops from the saline and cycloheximide-injected rabbits, mucosa was stripped from underlying muscularis with the edge of a glass microscope slide, minced, and then incubated in $25-\mathrm{ml}$ Erlenmeyer flasks containing $2.5 \mathrm{ml}$ of the $\mathrm{HCO}_{3}$-Ringer solution described above, to which had been added $2.0 \times 10^{-2} \mathrm{M}$ glucose and $8.0 \times 10^{-6} \mathrm{M}$ L-leucine, containing $0.4 \mu \mathrm{Ci}$ of $\mathrm{L}-\left[{ }^{14} \mathrm{C}\right]$ leucine (uniformly labeled). The $L-\left[{ }^{14} \mathrm{C}\right]$ leucine was purchased from New England Nuclear at an original specific activity of $250 \mu \mathrm{Ci}$ per $\mu \mathrm{mol}$. Triplicate flasks were incubated with the mucosa (about $300 \mathrm{mg}$ wet wt per flask) from each loop. Each flask was agitated at $80 \mathrm{rpm}$ and incubated at $37^{\circ} \mathrm{C}$ for $30 \mathrm{~min}$ while being continuously gassed in an atmosphere of $95 \% \mathrm{O}_{2}-5 \%$

${ }^{8}$ Purified cholera toxin, lot 1071 , prepared according to procedure described in J. Infect. Dis. 121 (Suppl.): S63, 1970 , and under contract for the National Institute of A1lergy and Infectious Diseases by R. A. Finkelstein, Ph.D., The University of Texas, Southwestern Medical School, Dallas, Tex.

Cycloheximide and Cholera Enterotoxin 
$\mathrm{CO}_{2}$. At the termination of the incubation protein was precipitated with $5 \%$ trichloroacetic acid (TCA), isolated by the method of Siekevitz (25), and dissolved in $2 \mathrm{ml}$ of 1 $\mathrm{N} \mathrm{NaOH}$ for determination of protein (26) and for suspension in $10 \mathrm{ml}$ of Bray's solution (27) and 2\% Cab-O-Sil (Cabot Corp., Boston, Mass.). Samples were counted in a model SL40 Intertechnique Liquid Scintillation Spectrometer at an efficiency of $70-80 \%$ as determined by internal standardization.

In certain experiments the incorporation of $\mathrm{L}-\left[{ }^{14} \mathrm{C}\right]$ leucine into protein was also assessed in mounted preparations of stripped ileal mucosa. These studies were undertaken in order to insure that the cycloheximide effect on protein synthesis persisted in tissues mounted in the chambers in vitro and exposed for prolonged periods to large volumes of cycloheximide-containing medium in the reservoirs. Furthermore, it was considered desirable to ascertain whether the cycloheximide effect on $\mathrm{L}-\left[{ }^{14} \mathrm{C}\right]$ leucine incorporation noted with ileal mucosa exposed to incubation medium in Erlenmeyer flasks could simply be due to an influence of the antibiotic on the uptake of L-leucine at the mucosal surface. For this purpose, ileal mucosa stripped of its muscularis was obtained from control and cycloheximide-injected rabbits $1 \mathrm{~h}$ after the in vivo administration of the antibiotic. The tissues were mounted and incubated in the chambers as previously described, except that the reservoirs each contained $7.5 \mathrm{ml}$ of $\mathrm{HCO}_{3}$-Ringer solution. Cycloheximide, at a concentration of $5.0 \times 10^{-5} \mathrm{M}$ was present in both the mucosal and serosal reservoirs of those chambers containing tissues from cycloheximide pretreated animals. At the initiation of the $2 \mathrm{~h}$ incubation, purified CT at a final concentration of $1 \mu \mathrm{g}$ per $\mathrm{ml}$ was added on the mucosal side to one of the two tissues prepared from each animal. $1 \frac{1}{2} \mathrm{~h}$ later, L-leucine at a final concentration of $8.0 \times 10^{-6} \mathrm{M}$ and containing $2 \mu \mathrm{Ci}$ of $\mathrm{L}-\left[{ }^{14} \mathrm{C}\right]$ leucine was added to the serosal reservoir. After an additional $30 \mathrm{~min}$ of incubation, both reservoirs were clamped, the chambers were removed, and a representative sample of the exposed tissue was rapidly plunged into 5\% TCA. The methods for the subsequent preparation of the samples for protein determinations and for liquid scintillation counting have already been described.

Adenyl cyclase assays. Immediately after the removal of the two ileal loops from each of the control and cycloheximide-treated rabbits, ileal mucosa stripped of its muscularis was homogenized and membranes were prepared for assay of adenyl cyclase activity by a previously described (11) modification of the procedure of Krishna, Weiss, and Brodie (28). In certain experiments, assays for adenyl cyclase activity were conducted with membranes from both the control and CT-exposed loops of control and cycloheximide-pretreated rabbits with $2.85 \times 10^{-3} \mathrm{M}$ cycloheximide present in the incubation medium. All determinations of adenyl cyclase activity were routinely done in triplicate.

Cyclic AMP measurements. As indicated previously, fullthickness biopsies of each loop were obtained while the circulation was still intact, just before the removal of the loops from the animals. Biopsy samples were immediately plunged into ice-cold $5 \%$ TCA containing $\left[{ }^{3} \mathrm{H}\right]$ cyclic AMP as a recovery marker. After homogenization and centrifugation, $\mathrm{HCl}$ was added to supernates to a concentration of $0.1 \mathrm{~N}$ and the TCA was extracted with diethyl ether. Supernates were then evaporated to dryness at $50^{\circ} \mathrm{C}$ using an evapomix evaporator (Buchler Instruments Div., Nuclear-Chicago Corp., Fort Lee, N. J.). The residues were redissolved in $50 \mathrm{mM}$ acetate buffer, $\mathrm{pH} 4.0$ and cyclic AMP levels
TABLE I

Effects of CT and Cycloheximide Administration on Ileal Fluid Secretion In Vivo

\begin{tabular}{|c|c|c|}
\hline \multirow{2}{*}{ Animal treatment } & \multicolumn{2}{|c|}{ Fluid accumulation } \\
\hline & Control loop & Cholera loop \\
\hline & \multicolumn{2}{|c|}{ ml per cm loop length } \\
\hline Control $(n=11)$ & \multicolumn{2}{|c|}{$(P<0.001)$} \\
\hline Cycloheximide $(\mathrm{n}=10)$ & $0.03 \pm 0.02$ & $0.25 \pm 0.08$ \\
\hline
\end{tabular}

Values are means \pm 1 SEM. $\mathrm{n}$ refers to the number of animals. Probabilities represented in this table were determined by Student's $t$ test for paired variates. By the method for unpaired variates, the difference between control loops from control and cycloheximide-treated animals was not significant, whereas the difference between the CT-exposed loops was significant with a value of $P<0.005$.

were then measured by the protein-kinase binding assay described by Gilman (29). Results were expressed as picomoles cyclic AMP per milligram protein. Protein was determined on the TCA precipitates as described above. Duplicate biopsies were obtained from each loop, and duplicate determinations of cyclic AMP levels were performed on each sample.

\section{RESULTS}

Effects of CT and cycloheximide on ileal fluid secretion in vivo. The results presented in Table I demonstrate that the in vivo application of $\mathrm{CT}$ is capable of inducing a brisk small intestinal secretory response in control animals. Consistent with the observations of others made on rabbit jejunum $(20-23)$, the prior administration of cycloheximide failed to significantly affect the rate of fluid accumulation in control loops of ileum, but it did impair the secretory response in loops exposed to CT.

Effects of CT (added in vivo) and of cycloheximide (added in vivo and in vitro) on $\mathrm{Na}$ and $\mathrm{Cl}$ fluxes and $S C C$ measured in vitro. In order to assess the direct effects of cycloheximide on the mucosal secretory response to CT (as contrasted to possible indirect effects of the drug on mucosal blood flow or hormonal or neurogenic intermediates), it seemed desirable to explore the effects of cycloheximide using isolated ileal mucosa in vitro. For this purpose, ileal mucosa stripped of its muscularis was obtained from isolated intestinal loops prepared in control and cycloheximide-pretreated rabbits, the loops having been exposed in vivo to either $\mathrm{HCO}_{\text {:- }}$ Ringer solution or to the same solution containing purified CT. In order to insure continued inhibition of protein synthesis during the in vitro incubation of tissues from cycloheximide pretreated animals, cycloheximide $\left(5.0 \times 10^{-5} \mathrm{M}\right)$ was added to both mucosal and serosal 
TABLE II

Effects of CT In Vivo and of Cycloheximide In Vivo and In Vitro on Ion Fluxes and SCC

\begin{tabular}{|c|c|c|c|c|c|c|c|c|c|}
\hline \multirow{2}{*}{$\begin{array}{c}\text { Animal } \\
\text { treatment }\end{array}$} & \multicolumn{3}{|c|}{$\mathrm{Na}$ fluxes } & \multicolumn{3}{|c|}{$\mathrm{Cl}$ fluxes } & \multirow[b]{2}{*}{ SCC } & \multirow[b]{2}{*}{ Conductance } & \multirow{2}{*}{$\begin{array}{c}\text { +cyclic } \\
\text { DbAMP } \\
\Delta \text { SCC }\end{array}$} \\
\hline & $\mathrm{m} \rightarrow \mathrm{s}$ & $\mathrm{s} \rightarrow \mathrm{m}$ & net & $\mathrm{m} \rightarrow \mathrm{s}$ & $\mathrm{s} \rightarrow \mathrm{m}$ & net & & & \\
\hline & \multicolumn{3}{|c|}{$\mu e q / h \mathrm{~cm}^{2}$} & \multirow{2}{*}{\multicolumn{3}{|c|}{$\mu \mathrm{eq} / \mathrm{h} \mathrm{cm}^{2}$}} & $\mu e q / h \mathrm{~cm}^{2}$ & $m m h o s / c m^{2}$ & $\mu e q / h \mathrm{~cm}^{2}$ \\
\hline \multicolumn{7}{|c|}{ Control animals $(n=4)$} & & & \\
\hline Control loop & $10.1 \pm 1.4$ & $9.0 \pm 0.7$ & $1.0 \pm 0.8$ & $8.3 \pm 1.0$ & $8.3 \pm 0.3$ & $0.0 \pm 0.8$ & $2.5 \pm 0.9$ & $25.2 \pm 3.7$ & $2.7 \pm 0.5$ \\
\hline Cholera loop & $6.4 \pm 0.6$ & $7.5 \pm 0.8$ & $-1.1 \pm 0.3$ & $4.4 \pm 0.4$ & $7.6 \pm 0.8$ & $-3.2 \pm 0.5$ & $3.1 \pm 0.3$ & $20.7 \pm 5.9$ & $0.7 \pm 0.1$ \\
\hline$P$ & NS & NS & NS & $<0.02$ & NS & $<0.01$ & NS & NS & $<0.01$ \\
\hline \multicolumn{10}{|c|}{ Cycloheximide animals $(\mathrm{n}=6)$} \\
\hline Control loop & $12.5 \pm 0.7$ & $12.1 \pm 0.6$ & $0.4 \pm 0.7$ & $11.6 \pm 1.2$ & $10.5 \pm 0.7$ & $1.1 \pm 1.0$ & $1.2 \pm 0.4$ & $28.9 \pm 3.1$ & $1.9 \pm 0.2$ \\
\hline Cholera loop & $9.8 \pm 0.7$ & $10.7 \pm 1.1$ & $-0.9 \pm 0.6$ & $8.0 \pm 0.9$ & $9.3 \pm 0.8$ & $-1.3 \pm 0.2$ & $3.1 \pm 0.1$ & $28.6 \pm 3.5$ & $0.3 \pm 0.1$ \\
\hline$P$ & $<0.02$ & NS & NS & $<0.05$ & NS & $<0.05$ & $<0.001$ & NS & $<0.001$ \\
\hline
\end{tabular}

Cyclic DbAMP, dibutyryl cyclic AMP. Values are means \pm 1 SEM. $n$ refers to the number of animals. Probabilities represented in this table were determined by Student's $t$ test for paired variates (NS $=>0.05$ ). By the method for unpaired variates, there were no significant differences between the values for net $\mathrm{Na}$ and $\mathrm{Cl}$ fluxes and $\mathrm{SCC}$ in the control loops of control and cycloheximide-treated animals. Similarly, there were no significant differences between the net $\mathrm{Na}$ flux and the SCC in the choleraexposed loops of control and cycloheximide-treated animals. The effect of cycloheximide on the net $\mathrm{Cl}$ flux in the choleraexposed loops was significant with a value of $P<0.005$. Also, the $\mathrm{m}$ to $\mathrm{s}$ unidirectional fluxes of $\mathrm{Na}$ and $\mathrm{Cl}$ were significantly greater in the cholera loops of cycloheximide-treated animals than in the cholera loops of control animals $(P<0.01$ and $P<0.02$, respectively).

reservoirs. As shown in Table II, in tissues obtained from the control loops of the control animals, there were net absorptive fluxes of both $\mathrm{Na}$ and $\mathrm{Cl}$, whereas in tissues from CT-exposed loops from the same animals, the small net absorptive $\mathrm{Na}$ flux disappeared, and the net absorptive flux of $\mathrm{Cl}$ was replaced by a net secretory flux. The residual ion flux ( SCC - net $\mathrm{Na}$ flux + net $\mathrm{Cl}$ flux), probably due to $\mathrm{HCO}_{3}$ secretion," did not change significantly. The average $\mathrm{SCC}$ in the CT-exposed tissues during the period of steady-state flux measurements differed little from the control values. The increase in SCC following the in vitro addition of dibutyryl cyclic AMP to the serosal surface has been shown to reflect an increase in the net $\mathrm{Cl}$ secretory response (8). Whereas the addition of this nucleotide increased SCC in tissues from both the control and CT-exposed loops of control animals, the response was of much smaller magnitude in the enterotoxin-exposed tissues, suggesting that an enterotoxin-induced $\mathrm{Cl}$ secretory response was already occurring, and that this response involved a pathway common to that following cyclic AMP addition (7).

As shown in Table II, when mucosa from the cycloheximide-pretreated animals was studied in vitro in the continued presence of the antibiotic, CT induced changes in the net $\mathrm{Na}$ and $\mathrm{Cl}$ fluxes and in the SCC similar in direction to those which occurred in the control animals. Furthermore, in a manner characteristic of a tissue responding to CT, the SCC-response to dibutyryl cyclic AMP was blunted in mucosa obtained from the entero-

\footnotetext{
"Dietz, J., and M. Field. Ion transport in rabbit ileal
} mucosa. IV. Bicarbonate secretion. Submitted for publication. toxin-pretreated loop. Of great significance however, is the fact that the net $\mathrm{Cl}$ secretory flux in the enterotoxinexposed mucosa from the cycloheximide-pretreated animals was substantially less than that noted in enterotoxin-treated mucosa from control animals. It seems clear then, that exposure to cycloheximide interferes with the secretory response of the intestinal epithelium to CT and that this effect is probably not mediated by secondary humoral, neurogenic, or vascular influences in the intact animal.

Effects of cycloheximide on $\mathrm{L}-\left[{ }^{14} \mathrm{C}\right]$ leucine incorporation into mucosal protein. Cycloheximide in the doses employed in the present study has been used extensively in experiments concerned with the mechanisms underlying CT-induced intestinal fluid and electrolyte losses (20-23). Furthermore, the effects of the antibiotic in this system have been attributed to its ability to inhibit the synthesis of a protein or proteins induced by the enterotoxin and required in the secretory process $(20$, 21). It seemed desirable therefore, to obtain more direct evidence than the histologic data previously provided $(20-22)$ to support the contention that the treatment regimen employed does indeed inhibit the synthesis of protein in rabbit mucosa.

The results of initial experiments performed in this regard are shown in Table III. In these studies ileal mucosa stripped of its muscularis was minced and incubated in Erlenmeyer flasks containing $\mathrm{L}-\left[{ }^{14} \mathrm{C}\right]$ leucine as described in the section on Methods. Rates of $\mathrm{L}-\left[{ }^{14} \mathrm{C}\right]-$ leucine incorporation into mucosal protein from animals. pretreated with cycloheximide were less than $10 \%$ of 
TABLE III

Effects of CT and Cycloheximide Administration on $L-\left[{ }^{14} C\right]-$ Leucine Incorporation into Mucosal Protein

\begin{tabular}{|c|c|c|}
\hline \multirow[b]{2}{*}{ Animal treatment } & \multicolumn{2}{|c|}{$\mathrm{L}-\left[{ }^{14} \mathrm{C}\right]$ leucine incorporated } \\
\hline & Control loop & Cholera loop \\
\hline & \multicolumn{2}{|c|}{ nmol leucine $\times 10^{-3} / \mathrm{mg}$ protein } \\
\hline Control $(n=4)$ & $(P>0.1)$ & $248.9 \pm 63.9$ \\
\hline Cycloheximide $(n=4)$ & $15.6 \pm 3.8$ & $24.3 \pm 4.9$ \\
\hline
\end{tabular}

Values are means \pm 1 SEM. $\mathrm{n}$ refers to the number of animals. Probabilities represented in the table were determined by Student's $t$ test for paired variates. By the method for unpaired variates, the effects of cycloheximide in mucosa from both the control and CT-exposed loops were significant at the level of $P<0.01$.

control values with mucosa from either the control or CT-exposed loops. The slight enhancement of the rate of incorporation of $\mathrm{L}-\left[{ }^{14} \mathrm{C}\right]$ leucine into protein in tissues exposed to $\mathrm{CT}$ and obtained from cycloheximide-pretreated animals was not observed in subsequent experiments described below, and its significance remains unresolved.

In order to eliminate the possibility that cyclohexinide affected $\mathrm{L}-\left[{ }^{14} \mathrm{C}\right]$ leucine incorporation into protein by virtue of a primary effect on leucine uptake across the brush border, and in order to assure that mucosal protein synthesis was inhibited under the conditions employed for the in vitro flux studies (see above), incorporation of $\mathrm{L}-\left[{ }^{14} \mathrm{C}\right]$ leucine into mucosal protein of tissues mounted in flux chambers was determined with leucine added on the serosal side only. The results of these

TABLE IV

Effects of CT and Cycloheximide on $L-\left[{ }^{14} C\right]$ Leucine Incorporation into Mucosal Protein after Serosal Addition of Leucine to Tissues Mounted in Modified Ussing Chambers

\begin{tabular}{|c|c|c|}
\hline \multirow[b]{2}{*}{ Animal treatment } & \multicolumn{2}{|c|}{$\mathbf{L}-\left[{ }^{14} \mathrm{C}\right]$ leucine incorporated } \\
\hline & Control loop & Cholera loop \\
\hline & \multicolumn{2}{|c|}{ nmol leucine $\times 10^{-3} / \mathrm{mg}$ protein } \\
\hline Control $(n=4)$ & $(P>0.5)$ & 5) $35.3 \pm 6.4$ \\
\hline Cycloheximide $(n=4)$ & \multicolumn{2}{|c|}{$(P>0.5)$} \\
\hline
\end{tabular}

Values are means $\pm 1 \mathrm{SEM} . \mathrm{n}$ refers to the number of animals. Probabilities represented in the table were determined by Student's $t$ test for paired variates. By the method for unpaired variates, the effects of cycloheximide in tissues from both the control and CT-exposed loops were significant at the.level of $P<0.005$. studies presented in Table IV indicate that quite independently of possible effects of cycloheximide on mucosal leucine uptake, the antibiotic is a potent inhibitor of protein synthesis under conditions similar to those employed in the flux studies. Of note is the fact that less than $0.1 \%$ of the radioactivity added to the serosal resorvoir appeared in the mucosal reservoir.

Effects of CT and cycloheximide on adenyl cyclase activity and cyclic AMP levels. In view of the $3-4 \mathrm{~h}$ delay in obtaining a peak physiologic effect of the enterotoxin on the intestine $(4,7,11,16,19)$ and the known effects of cycloheximide on this physiologic response (20-23), the effects of this inhibitor of protein synthesis on the CT-induced increase in intestinal mucosal adenyl cyclase activity and cyclic AMP levels were examined. Previous studies conducted in this laboratory suggested that CT stimulates existing adenyl cyclase in the intestinal mucosa rather than causing the synthesis of new enzyme (11); this conclusion, however, was regarded as only tentative.

As shown in Table $\mathrm{V}$, despite the profound degree of inhibition of protein synthesis caused by cycloheximide, adenyl cyclase activity in mucosal membranes prepared from the control and cycloheximide-treated animals was very much the same. Moreover, even though cycloheximide was quite effective in reducing CT-stimulated fluid secretion in vivo and in diminishing the net $\mathrm{Cl}$ secretory flux in vitro, this agent failed to prevent the enterotoxinrelated increase in cyclase activity. Of note too is the fact that cycloheximide added in vitro to the adenyl cyclase reaction mixtures in concentrations as high as 2.85 $\times 10^{-3} \mathrm{M}$ failed to exert any influence on adenyl cyclase activity with membranes prepared from either the control or enterotoxin-exposed mucosa from either control or cycloheximide-treated animals (results not shown).

\section{TABLE V}

Effects of Cycloheximide Administration and CT In Vivo on Intestinal Mucosal Adenyl Cyclase Activity

\begin{tabular}{|c|c|c|}
\hline \multirow[b]{2}{*}{ Animal treatment } & \multicolumn{2}{|c|}{ Adenyl cyclase activity } \\
\hline & Control loop & Cholera loop \\
\hline & \multicolumn{2}{|c|}{$\begin{array}{c}\text { nmol cyclic } A M P \text { formed } / \mathrm{mg} \\
\text { protein per } 10 \mathrm{~min}\end{array}$} \\
\hline Control $(n=4)$ & $0.23 \pm 0.04$ & $0.55 \pm 0.11$ \\
\hline Cycloheximide $(\mathrm{n}=4)$ & $(P<0.05)$ & $0.50 \pm 0.07$ \\
\hline
\end{tabular}

Values are means \pm 1 SEM. $\mathrm{n}$ refers to the number of animals. Probabilities represented in the table were determined by Student's $t$ test for paired variates. The effects of cycloheximide on adenyl cyclase activity were not significant by the method for unpaired variates $(P>0.5)$.

1380 D. V. Kimberg, M. Field, E. Gershon, R. T. Schooley, and A. Henderson 
Cyclic AMP levels measured in biopsies of control and enterotoxin-exposed loops in control and cycloheximidetreated rabbits are shown in Table VI. Cyclic AMP levels were determined in full thickness biopsies in order to avoid the secondary effects of the delay in removing mucosa. Cyclic AMP levels measured on mucosal scrapings gave similar but more erratic results (results not shown). As one might anticipate from the results of the adenyl cyclase assays (Table V), cycloheximide administration in vivo did not prevent the usual CT-induced increase in intestinal cyclic AMP levels.

\section{DISCUSSION}

The present study confirms and extends previous observations (20-23) concerned with the effects of cycloheximide on small intestinal fluid and electrolyte secretion after exposure to CT. Thus, the administration of cycloheximide to rabbits in doses shown in this study to be capable of inhibiting intestinal mucosal protein synthesis by greater than $90 \%$, does indeed reduce the sma!l intestinal secretory response to subsequent challenge with CT. Furthermore, the experiments concerned with the influence of cycloheximide administration on the in vitro fluxes of $\mathrm{Na}$ and $\mathrm{Cl}$ across ileal mucosa from control and CT-exposed small bowel loops suggest that the in vivo effects of this antibiotic are due, in part at least, to a direct interaction with the active ion transport processes of the intestinal epithelium.

The delayed stimulation of intestinal mucosal adenyl cyclase appears to be an essential step in mediating the effects of CT on intestinal ion transport $(4,11,14,15$, 19). The precise manner in which the enterotoxin stimulates this activity has not been fully resolved. The following possibilities deserve consideration: $(a)$ the enterotoxin may, either directly or indirectly, cause a delayed stimulation of existing membrane cyclase; $(b)$ the enterotoxin may stimulate the synthesis of new cyclase; $(c)$ once combined with a component of the cell membrane, the enterotoxin may itself catalyze the formation of cyclic AMP in a manner analagous to the way in which diphtheria exotoxin catalyzes the cleavage of nicotinamide adenine dinucleotide to nicotinamide and adenosine diphosphoribose (30).

The results of the present study clearly demonstrate that the administration of cycloheximide does not prevent the CT-induced increase in intestinal mucosal adenyl cyclase activity and cyclic AMP levels, suggesting that the synthesis of new adenyl cyclase or of a protein which modifies its activity is not involved. Furthermore, the effects of cycloheximide noted in this study do not seem to be mediated simply by preventing the interaction of $\mathrm{CT}$ with existing adenyl cyclase. Analagous results have been obtained in another study concerned with the effects
TABLE VI

Effects of Cycloheximide Administration and CT In Vivo on Intestinal Cyclic AMP Levels

\begin{tabular}{|c|c|c|}
\hline \multirow[b]{2}{*}{ Animal treatment } & \multicolumn{2}{|c|}{ Cyclic AMP level } \\
\hline & Control loop & Cholera loop \\
\hline & \multicolumn{2}{|c|}{ pmol cyclic $A M P / m g$ protein } \\
\hline Control $(n=11)$ & \multicolumn{2}{|c|}{$(P<0.02)$} \\
\hline Cycloheximide $(\mathrm{n}=10)$ & $8.49 \pm 0.93$ & $15.09 \pm 2.93$ \\
\hline
\end{tabular}

Values are means \pm 1 SEM. $\mathrm{n}$ refers to the number of animals. Probabilities represented in the table were determined by Student's $t$ test for paired variates. The effects of cycloheximide on cyclic AMP levels were not significant by the method for unpaired variates $(P>0.5)$.

of cycloheximide administration in the rat on hepatic adenyl cyclase activity and cyclic AMP levels.

The changes in SCC produced by dibutyryl cyclic AMP provide further evidence that the effect of cycloheximide on intestinal ion transport cannot be due to an interference with the CT-adenyl cyclase interaction. Addition of dibutyryl cyclic AMP to CT-treated tissues from cycloheximide animals did not result in a significant increase in SCC. If the inhibition by cycloheximide of CT-induced secretion had been secondary to an effect on the specific adenyl cyclase involved with ion transport, then addition of dibutyryl cyclic AMP should have by-passed this step and resulted in an increase in SCC (as seen in the tissues not treated with CT). This was not the case, however, suggesting that the secretory pump itself had been affected.

The cycloheximide inhibition of the secretory process must be considered as partial rather than total. This is reflected by both the volume fluxes measured in vivo (Table I) and the $\mathrm{Na}$ and $\mathrm{Cl}$ fluxes measured in vitro (Table II). It is also reflected by the SCC changes observed in vitro (Table II). Dibutyryl cyclic AMP did increase the SCC of control loop tissues from cycloheximide animals, but the sum of the base line SCC of these tissues and the increment in SCC produced by dibutyryl cyclic AMP $(1.18+1.91=3.09 \mu \mathrm{eq} / \mathrm{h} \mathrm{cm})$ is distinctly less than the corresponding sum for control loop tissues of control animals $\left(2.54+2.74=5.28 \mu \mathrm{eq} / \mathrm{h} \mathrm{cm} \mathrm{cm}^{2}\right)$.

Whether or not the effect of cycloheximide on active fluid secretion is directly related to the antibiotics's action as an inhibitor of protein biosynthesis or to selective damage to crypt cells, concepts which have been suggested by others $(20-22)$, remain to be determined.

${ }^{5}$ Baker, A. L., M. M. Kaplan, and D. V. Kimberg. Hepatic alkaline phosphatase: possible induction by cyclic AMP. Submitted for publication.

Cycloheximide and Cholera Enterotoxin 
Perhaps of significance in this regard are the observations of MacDonald and Ellis (31) and Evans (32). MacDonald and Ellis (31) recently demonstrated that cycloheximide is 10 times more effective on a molar basis than is 2,4-dinitrophenol in stimulating oxygen uptake by red beet discs incubated in vitro. These authors suggested that cycloheximide-related inhibition of chloride uptake by beet discs may not be a direct result of inhibition of protein synthesis, but rather may be the result of interference with metabolic processes such as energy transfer. Evans (32) has provided evidence to support the concept that cycloheximide-related inhibition of 2,4dinitrophenol uptake by Euglena gracilis is not a consequence of the inhibition of protein synthesis. While cycloheximide is known to inhibit protein biosynthesis, it does not follow a priori that its effects in many given system are the result of this particular action of the antibiotic. One must consider the possibility that cycloheximide may exert effects on membrane transport which are independent of its action as an inhibitor of protein synthesis.

The major alteration in small intestinal morphology after administration of the dose of cycloheximide employed in the present study and in others (20-23) is a decrease in mitotic figures in the undifferentiated crypt cells (20-22). Based upon the observation of these morphologic changes in association with cycloheximiderelated inhibition of fluid production by isolated small intestinal loops exposed to CT, Serebro and his coworkers (20) and others (22) suggested that crypt cells are responsible for the secretory response to the enterotoxin. The observation that glucose absorption from isolated loops in vivo was unaffected by cycloheximide administration was interpreted as further evidence in support of the concept that the antibiotic exerted a localized effect on the crypt cells (20). Studies by Frizzell, Nellans, Acheson, and Schultz (33) have provided reason for a great deal of caution in drawing conclusions concerning the site of enterotoxin-induced secretion from morphological evidence alone. These workers clearly demonstrated that the administration of the same dose of cycloheximide to rabbits markedly inhibited the mucosal influx processes for $\mathrm{Na}, \mathrm{Cl}$, alanine, 3- $O$-methylglucose, and iron across brush borders. These influx processes are, for the most part, localized in the mature villus absorptive cells. The results, while consistent with the notion that cycloheximide may inhibit the synthesis of protein(s) which are either directly or indirectly involved in carrier-mediated transport, also indicate that the effect of the antibiotic is not restricted to the crypt cell population.

Based on the results of the present study it can be concluded that the cycloheximide inhibition occurs at some step in the secretory process other than the ac- tivation of adenyl cyclase by CT. Whether or not the antibiotic inhibits secretion by virtue of its action as an inhibitor of protein synthesis, and whether or not the enterotoxin-stimulated secretory process is largely a crypt cell function remain uncertain; further studies will be required in order to resolve these important issues.

\section{ACKNOWLEDGMENTS}

This work was supported by Grants AM-13696, AM-05114, and CA-10736 from the National Institutes of Health, Department of Health, Education and Welfare, and by the United States-Japan Cooperative Medical Science Program administered by the National Institute of Allergy and Infectious Diseases of the National Institutes of Health (Grant AI-09029).

\section{REFERENCES}

1. Banwell, J. G., N. F. Pierce, R. C. Mitra, K. L. Brigham, G. J. Caranasos, R. I. Keimowitz, D. S. Fedson, J. Thomas, S. L. Gorbach, R. B. Sack, and A. Mondal. 1970. Intestinal fluid and electrolyte transport in human cholera. J. Clin. Invest. $49: 183$.

2. Iber, F. L., T. J. McGonagle, H. A. Serebro, E. H Luebbers, T. M. Bayless, and T. R. Hendrix 1969. Unidirectional sodium flux in small intestine in experimental canine cholera. Am. J. Med. Sci. 258: 340.

3. Hendrix, T. R., and T. M. Bayless. 1970. Digestion: intestinal secretion. Annu. Rev. Physiol. 32: 139.

4. Field, M. 1971. Intestinal secretion: effect of cyclic AMP and its role in cholera. N. Engl. J. Med. 284: 1137.

5. Carpenter, C. C. J., Jr. 1971. Cholera enterotoxin-recent investigations yield insights into transport processes. Am. J. Med. 50: 1 .

6. Pierce, N. F., W. B. Greenough, III, and C. C. J. Carpenter, Jr. 1971. Vibrio cholerae enterotoxin and its mode of action. Bacteriol. Rev. 35: 1.

7. Field, M., D. Fromm, Q. Al-Awqati, and W. B. Greenough, III. 1972. Effect of cholera enterotoxin on ion transport across isolated ileal mucosa. J. Clin. Invest. $51: 796$.

8. Field, M. 1971. Ion transport in rabbit ileal mucosa. II. Effects of cyclic 3',5'-AMP. Am. J. Physiol. 221: 992.

9. Al-Awqati, Q., and W. B. Greenough, III. 1972. Prostaglandins inhibit intestinal sodium transport. Nat. New Biol. 238 : 26.

10. Pierce, N. F., C. C. J. Carpenter, H. L. Elliott, and W. B. Greenough, III. 1971. Effects of prostaglandins, theophylline and cholera exotoxin upon transmucosal water and electrolyte movement in canine jejunum. Gastroenterology. $60: 22$.

11. Kimberg, D. V., M. Field, J. Johnson, A. Henderson, and E. Gershon. 1971. Stimulation of intestinal mucosal adenyl cyclase by cholera entertoxin and prostaglandins. J. Clin. Invest. 50: 1218.

12. Vaughan, M., N. F. Pierce, and W. B. Greenough, III. 1970. Stimulation of glycerol production in fat cells by cholera toxin. Nature (Lond.). 226: 658.

13. Zieve, P. D., N. F. Pierce, and W. B. Greenough, III. 1970. Stimulation of glycogenolysis by purified cholera enterotoxin in disrupted cells. Clin. Res. 18: 690.

14. Schafer, D. E., W. D. Lust, R. Sircar, and N. D. Goldberg. 1970. Elevated concentration of adenosine $3^{\prime}, 5^{\prime}-$ cyclic monophosphate in intestinal mucosa after treat- 
ment with cholera toxin. Proc. Natl. Acad. Sci. U. S. A. $67: 851$.

15. Sharp, G. W. G., and S. Hynie. 1971. Stimulation of intestinal adenyl cyclase by cholera toxin. Nature (Lond.). 229: 266.

16. Carpenter, C. C. J., R. B. Sack, J. C. Feeley, and R. W. Steenberg. 1968. Site and characteristics of electrolyte loss and effect of intraluminal glucose in experimental canine cholera. J. Clin. Invest. 47: 1210.

17. Craig, J. P. 1965. A permeability factor (toxin) found in cholera stools and culture filtrates and its neutralization by convalesment cholera sera. Nature (Lond.). 207: 614.

18. Graybill, J. R., M. M. Kaplan, and N. F. Pierce. 1970 Hormone-like effects of cholera exotoxin. Clin. Res. 18: 454.

19. Guerrant, R. L., L. C. Chen, and G. W. G. Sharp. 1972. Intestinal adenyl-cyclase activity in canine cholera: correlation with fluid accumulation. J. Infect. Dis. 125: 377.

20. Serebro, H. A., F. L. Iber, J. H. Yardley, and T. H. Hendrix. 1969. Inhibition of cholera toxin action in the rabbit by cycloheximide. Gastroenterology. 56: 506.

21. Grayer, D. T., H. A. Serebro, F. L. Iber, and T. R. Hendrix. 1970. Effect of cycloheximide on unidirectional sodium fluxes in the jejunum after cholera exotoxin exposure. Gastroenterology. 58: 815.

22. Harper, D. T., Jr., J. H. Yardley, and T. R. Hendrix. 1970. Reversal of cholera exotoxin-induced jejunal secretion by cycloheximide. Johns Hopkins Med. J. 126: 258.

23. Moritz, M., F. L. Iber, and E. W. Moore. 1972. Rabbit cholera: effects of cycloheximide on net water and ion fluxes and transmural electric potentials. Gastroenterology. $63: 76$.
24. Field, M., D. Fromm, and I. McColl. 1971. Ion transport in rabbit ileal mucosa. I. $\mathrm{Na}$ and $\mathrm{Cl}$ fluxes and short-circuit current. Am. J. Physiol. 220: 1388.

25. Siekevitz, P. 1952. Uptake of radioactive alanine in vitro into the proteins of rat liver fractions. J. Biol. Chem. 195 : 549.

26. Lowry, O. H., N. J. Rosebrough, A. L. Farr, and R. J. Randall. 1951. Protein measurement with the Folin phenol reagent. J. Biol. Chem. 193: 265.

27. Bray, G. 1960. A simple efficient liquid scintillator for counting aqueous solutions in a liquid scintillation counter. Anal. Biochem. 1: 279.

28. Krishna, G., B. Weiss, and B. B. Brodie. 1968. A simple, sensitive method for the assay of adenyl cyclase. $J$. Pharmacol. Exp. Ther. 163: 379.

29. Gilman, A. G. 1970. A protein binding assay for adenosine 3',5'-cyclic monophosphate. Proc. Natl. Acad. Sci. U.S. A. $67: 305$.

30. Gill, D. M., A. M. Pappenheimer, Jr., R. Brown, and J. T. Kurnich. 1969. Studies on the mode of action of diphtheria toxin. VII. Toxin-stimulated hydrolysis of nicotinamide adenine dinucleotide in mammalian cell extracts. J. Exp. Med. 129 : 1.

31. MacDonald, I. R., and R. J. Ellis. 1969. Does cycloheximide inhibit protein synthesis specifically in plant tissues? Nature (Lond.). 222 : 791.

32. Evans, W. R. 1971. The effect of cycloheximide on membrane transport in Euglena. A comparative study with nigercin. J. Biol. Chem. 246: 6144.

33. Frizzell, R. A., H. N. Nellans, L. S. Acheson, and S. G. Schultz. 1973. Effects of cycloheximide on influx across the brush border of rabbit small intestine. Biochim. Biophys. Acta. 291 : 302. 